\title{
Measurement of $\beta$-glucan and other nutritional characteristics in distinct strains of Agaricus subrufescens mushrooms
}

\author{
Rômulo César Clemente Toledo ${ }^{1}$, Maiara Andrade Carvalho ${ }^{1}$, Luiz Carlos Oliveira Lima ${ }^{2}$, \\ Eduardo Valério de Barros Vilas-Boas ${ }^{2}$ and Eustáquio Souza Dias ${ }^{1^{*}}$
}

1 Departamento de Biologia, UFLA, Campus Universitário, CEP 37200-000, Caixa Postal 3037, Lavras, MG, Brasil.
${ }^{2}$ Departamento de Ciência e Tecnologia de Alimentos, UFLA, Campus Universitário, CEP 37200-000, Caixa Postal 3037, Lavras, MG, Brasil.

Accepted 25 September, 2013

\begin{abstract}
$\beta$-Glucan is a polysaccharide with anticancer properties, and it is present in the mushroom Agaricus subrufescens. The aim of this study was to compare two analytical methods to quantify $\beta$-glucan in mushrooms and analyze the nutritional characteristics, the concentration of phenolic compounds and the mineral composition, for $A$. subrufescens strains. An enzymatic extraction was performed, and $\beta$ glucan was quantified by spectrophotometry and high performance liquid chromatography (HPLC). No significant differences were found between the two methods of quantification of $\beta$-glucan. The CS7 and CS10 strains were found to have greater amounts of $\beta$-glucan, similar to the levels found in Pleurotus eryngii and Pleurotus-sajor-caju. Pleurotus ostreatus and Lentinula edodes samples contained even higher amounts of $\beta$-glucan. Significant differences were found in the nutritional characteristics for all parameters assessed, except for fat content. There was no difference between the strains with regard to phenolic compounds or certain mineral components. Fresh $A$. subrufescens mushrooms are not considered to be a high-protein food. However, they are a good source of fiber and minerals, in addition to being low in fat. Spectrophotometry presents the advantages of being quicker and lower in cost; this technique may be suggested as the standard for measurement of the $\beta$-glucan.
\end{abstract}

Key words: $\beta$-Glucan, medicinal mushroom, royal sun mushroom, almond portobello.

\section{INTRODUCTION}

The nutritional quality of edible and/or medicinal mushrooms may vary according to species, cultivation substrate, environmental conditions and strain (Bonatti et al., 2004; Fan et al., 2007; Guardia et al., 2005; Liu et al., 2005; Ragunathan and Swaminathan, 2003; Toro et al., 2006). The mushroom Agaricus subrufescens has drawn the attention of the scientific community, due mainly to its medicinal properties; these properties include anticancer and antioxidant effects, which are characteristics that are associated with the cell wall components $(1 \rightarrow 6)-(1 \rightarrow 3)-\beta$ D-glucan and (1 $\rightarrow 4)$ - $\alpha$-glucan (Bellini et al., 2006; Dong et al., 2002; Firenzuoli et al., 2008; Huang and Mau, 2006; Machado et al., 2005). These polysaccharides have also been associated with the medicinal characteristics of other mushroom species, such as Pleurotus sp., Lentinula edodes and A. bisporus (Adams et al., 2008; Carbonero et al., 2006; Pramanik et al., 2007).

Studies of genetic diversity (Colauto et al., 2002; Tomizawa et al., 2007) have demonstrated that there are few differences between the various isolates of $A$. subrufescens cultivated in different regions of Brazil; however, some isolates are genetically distinct and are 
Table 1. Agaricus subrufescens strains used in the study and its origin.

\begin{tabular}{ll}
\hline Strain & Origin (City/State) \\
\hline CS1 & Vitória/ES* \\
CS5 & Araçatuba/SP* \\
CS7 & Porto Alegre/RS* \\
CS9 & Eloi Mendes/MG* \\
CS10 & Belo Horizonte/MG* \\
\hline
\end{tabular}

*ES, Espírito Santo State; SP, São Paulo State; MG, Minas Gerais State; RS, Rio Grande do Sul State.

considered to be different strains of $A$. subrufescens. These facts imply that distinct strains may have differences in their nutritional characteristics and in their $\beta$ glucan content. Investigating the amount of $\beta$-glucan and the nutritional and chemical constitution of these strains is of great importance for selecting strains for mushroom production and breeding and for obtaining new strains with desirable characteristics.

Several methods have been used for the extraction and quantification of $\beta$-glucans, and the results may vary according to the methods used (Dallies et al., 1998; Manzi and Pizzoferrato, 2001; Park et al., 2003; Rhee et al., 2008). Previously, there was no standard method that fulfilled the requirements of being both quick and highly reproducible for use in ordinal analysis in laboratories. Therefore, in addition to nutritional analysis of the chemical composition, we have tested two methods of $\beta$ glucan quantification in the $A$. subrufescens strains cultivated in Brazil.

\section{MATERIALS AND METHODS}

\section{Materials}

The phosphoric and sulfuric acids, sodium hydroxide, ethanol (95\%) and ether were obtained from Sigma-Aldrich (St. Louis, MO). The enzymes a-amylase (Termamyl120L, New Nordisk), protease (New Nordisk)andamyloglicosidase(AMG300,NewNordisk) were obtained from Novozymes Latin America (Araucaria, Parana, Brazil). The kit used for glucose quantification, containing 4-(dimethylamino)1,5dimethyl-2-phenylpyrazol-3-one $(0.025 \mathrm{M})$, phenol $(0.055 \mathrm{M})$, glycosidase $(1 \mathrm{U} / \mathrm{ml})$, peroxidase $(0.15 \mathrm{U} / \mathrm{ml})$ and the standard glucose, was obtained from Laborlab Ltd. (Guarulhos, São Paulo, Brazil).

\section{Mushroom strains and cultivation}

To measure the $\beta$-glucan content and the nutritional characteristics of $A$. subrufescens, five strains were used (CS1, CS5, CS7, CS9 and CS10) (Table 1). The amount of $\beta$-glucan obtained from $A$. subrufescens strains was compared with that of the following mushrooms: Pleurotus ostreatus (PO), Pleurotus eryngii (PE), Pleurotus-sajor-caju (PC), Lentinula edodes (LE) and Agaricus bisporus $(\mathrm{AB})$. All species were obtained from the fungi collection in the Laboratory of Edible Mushrooms in the Department of Biology at the Federal University of Lavras (UFLA).

All strains, including $A$. subrufescens, were maintained on Potato dextrose agar (PDA) medium. Spawn was prepared on paddy rice grains supplemented with $10 \%$ wheat bran, $2 \%$ gypsum and $2 \%$ limestone, using the methods of Siqueira et al. (2009). All mushrooms were produced from strains belonging to the fungi collection of the Laboratory of Edible Mushrooms, except for $L$. edodes, which was obtained from the local market. Pleurotus mushrooms were produced in sterilized substrate, using chopped bean straw that was autoclaved twice at $121^{\circ} \mathrm{C}$, according to the methods described by Dias et al. (2003). A. bisporus and $A$. subrufescens were cultivated according to the standard procedures for this mushroom, as described by Chang and Miles (2004) and Siqueira et al. (2011), using coastcross hay and sugar cane bagasse-based compost, supplemented with superphosphate $(1 \%)$, limestone (2\%), gypsum (2\%) and urea (2\%).

Mushrooms were cultivated in pots (Agaricus) or polypropylene bags (Pleurotus), in four replicates. Fruiting bodies were picked and dried for $24 \mathrm{~h}$ at approximately $60^{\circ} \mathrm{C}$ and were subsequently ground in a Wiley mill and homogenized.

\section{$\beta$-Glucan extraction}

Insoluble fiber, which is mainly composed of $\beta$-glucan (Manzi and Pizzoferrato, 2000) was extracted according to the method originally described by Prosky et al. (1988) with the modifications developed by the Japanese Food Analysis Center, as described by Park et al. (2003). $1 \mathrm{~g}$ of ground mushroom was added to a $500 \mathrm{~mL}$ Erlenmeyer flask containing $50 \mathrm{~mL}$ phosphate buffer $\left(80 \mathrm{mmol} \mathrm{L}^{-1}\right.$, $\mathrm{pH}$ 6.0). The sample was then subjected to three enzymatic treatment stages: A. $0.1 \mathrm{~mL}$ of thermostable a-amylase (Termamyl 120L, New Nordisk) was added, and the flask was incubated in a boiling water bath for $30 \mathrm{~min}$;, $0.1 \mathrm{~mL}$ of neutral bacterial protease (New Nordisk) was added, and the $\mathrm{pH}$ was adjusted to 7.5 with 25 $\mathrm{mmol} \mathrm{L}{ }^{-1} \mathrm{NaOH}$, followed by incubation for $30 \mathrm{~min}$ at $60^{\circ} \mathrm{C}$; C, 0.3 $\mathrm{mL}$ of amyloglucosidase (AMG 300, New Nordisk) was added, and the $\mathrm{pH}$ was adjusted to 4.5 , followed by incubation for $30 \mathrm{~min}$ at $60^{\circ} \mathrm{C}$.

After the three enzymatic stages, $200 \mathrm{~mL}$ of $95 \%$ ethyl alcohol was added to the solution and incubated at $60^{\circ} \mathrm{C}$ for $01 \mathrm{~h} 00$. The insoluble fiber that was precipitated from the ethanol was filtered with Whatman number 5B filter paper (samples were weighed before filtering and after fiber removal) and washed three times into a solution of $80 \%$ ethyl alcohol and $20 \%$ acetone. The fiber precipitate was subsequently dried at room temperature and carefully removed from the filter paper.

For the measurement of $\beta$-glucan concentrations in insoluble fiber, each sample was transferred to a $300 \mathrm{~mL}$ Erlenmeyer flask and hydrolyzed by adding $10 \mathrm{~mL}$ of $72 \% \mathrm{H}_{2} \mathrm{SO}_{4}$ and incubating at room temperature overnight. Distilled water $(140 \mathrm{~mL})$ was added, and the solution was incubated for $02 \mathrm{~h} 00$ in a boiling water bath. The $\mathrm{pH}$ of the solution was adjusted to 7.0 using $5 \mathrm{~mol} \mathrm{~L}^{-1} \mathrm{NaOH}$, and the final volume was adjusted to $250 \mathrm{~mL}$. The solution was then filtered with Whatman number 5B filter paper, followed by filtration with Durapore membrane with $0.22 \mu \mathrm{m}$ pores (Millipore).

\section{Quantification of $\beta$-glucan content by the enzymatic method}

Quantification of $\beta$-glucan based on the enzymatic release of glucose was performed according to McClear and Glennie-Holmes (1985). The kit has the following composition: Standard reactive (glucose solution $100 \mathrm{mg} \mathrm{dL}^{-1}$ ), enzyme reactive (glucose oxidase (EC 1.1.3.4) $\geq 0.001 \mathrm{~L} \mathrm{~K} \mathrm{U}^{-1}$, peroxidase $\left(E C\right.$ 1.11.1.7) $\geq 15.10^{-5} \mathrm{~L} \mathrm{~K}$ $\mathrm{U}^{-1}$ ), color reagent 1 (4-aminophenazone $25 \mathrm{~mol} \mathrm{~m}^{-3}, 920 \mathrm{~mol} \mathrm{~m}^{-3}$ Tris) and color reactive $2\left(55 \mathrm{~mol} \mathrm{~m}^{-3}\right.$ phenol). The working reagent was prepared by adding in a $250 \mathrm{~mL}$ volumetric flask containing 
$225 \mathrm{~mL}$ of distilled water, $12.5 \mathrm{~mL}$ of color reagent $1,12.5 \mathrm{~mL}$ of color reagent 2 and $0.75 \mathrm{~mL}$ enzyme reactive. The reaction was made of $2.0 \mathrm{~mL}$ of working reagent with $20 \mu \mathrm{L}$ of each sample after extraction for $15 \mathrm{~min}$ at $37^{\circ} \mathrm{C}$. Absorbance $(505 \mathrm{~nm})$ was measured with a UV-VISIBLE spectrophotometer, model UV-1601PC (Shimadzu, Corp., Japan). For standardization, the reaction was made of $2.0 \mathrm{~mL}$ of working reagent and $20 \mu \mathrm{L}$ of standard reactive in the same conditions described above. The results were analyzed using the following Equation 1:

$\beta-\operatorname{glucan}\left(\frac{g}{k g}\right)=A x f \times 0.9 \times 2.5$

Where, $A$ is the Reaction absorbance of each sample after acid treatment; $f=100 \mathrm{mg} \mathrm{dL}^{-1} / P$, where $\mathrm{P}$ is the standard absorbance $\left[20 \mu \mathrm{L}\right.$ standard reactive (glucose solution $100 \mathrm{mg} \mathrm{dL}^{-1}$ ) $+2.0 \mathrm{~mL}$ reactive work (glycosidase $\geq 3000 \mathrm{U}$; peroxidase $\geq 400 \mathrm{U}$; 4-aminofenazone $0.0015 \mathrm{~mol}$; TRIS buffer $0.0015 \mathrm{~mol}$; phenol $0.00275 \mathrm{~mol} ; \mathrm{pH} 7.4 \pm 0.1$ )]. Factor 0.9 : $162 / 180$, the factor of free glucose conversion that was determined for anhydrous glucose, which occurs in B-glucan (McClear and Glennie-Holmes (1985)); Factor 2.5: The conversion factor to convert from $\mathrm{mg} \mathrm{dL}^{-1}$ to $\mathrm{g} \mathrm{Kg}^{-1}$, once the final volume of the extraction is $250 \mathrm{~mL}$.

\section{Quantification of $\beta$-glucan content by HPLC}

For chromatographic analysis, samples were obtained using the previously described procedures. The samples were transferred from storage at -20 to $10^{\circ} \mathrm{C}$ and were kept at $10^{\circ} \mathrm{C}$ for approximately $12 \mathrm{~h} 00$. The samples were then left at room temperature for approximately $04 \mathrm{~h} 00$ before being analyzed. After temperature stabilization, $25 \mu \mathrm{L}$ of each sample was diluted by a factor of 20 with ultrapure water, which had been filtered through an ultrafilter Durapore membrane with a $0.20 \mu \mathrm{m}$ pore size (Millipore). A $20 \mu \mathrm{L}$ volume of the diluted sample was injected into the chromatograph for analysis.

Values were determined using the AOAC (1992) technique, as modified by Schwan et al. (2001) and Shimadzu (1998). A high performance liquid chromatograph (HPLC), model LC-10Ai (Shimadzu Corp., Japan) was used. It was equipped with refraction index detectors (model RID-10A). For measurement of glucose, a cationic exchange column was used (Shim-Pack SCR-101H) $(7.9$ $\mathrm{mm}$ in diameter $\times 30 \mathrm{~cm}$ in length). For carbohydrate measurement, the column was operated at room temperature, with a mobile phase of ultrapure water adjusted to $\mathrm{pH} 2.1$ and a flux of $0.6 \mathrm{~mL} \mathrm{~min}^{-1}$. Quantification was done by comparison with a glucose standard curve, which was made using certified standards (Supelco-SigmaAldrich, St. Louis, MO, USA). The results read in the HPLC were analyzed using the following Equation 2:

$$
\beta-\operatorname{glucan}\left(\frac{g}{100 g}\right)=G \times 0.9 \times 250
$$

Where, $\mathrm{G}$ is the Glucose concentration in $\mathrm{mg} / \mathrm{mL}$, determined using a standard curve; Factor 0.9: factor that accounts for the proportion of glucose coming from $\beta$-glucan; Factor 250: e conversion factor to convert from mg mL $\mathrm{mb}^{-1}$ to $\mathrm{Kg}^{-1}$, once the final extraction volume is $250 \mathrm{~mL}$.

\section{Chemical analysis}

Samples from different strains of $A$. subrufescens mushrooms were dried, ground in a Wiley Mill and homogenized. They were then conditioned in glass flasks (closed and kept under refrigeration at approximately $5^{\circ} \mathrm{C}$ ). Chemical analyses were performed with four replicates for each treatment.

The following procedures were carried out for chemical analysis, according to the methods adopted by AOAC (2000): Measurement of moisture by drying at $105^{\circ} \mathrm{C}$ for $06 \mathrm{~h} 00$, determination of fat content by ether extraction and gravimetry in a Soxhlet extractor, ash measurement by sample incineration and crude fiber measurement by acid digestion. The protein content was determined using the Kjeldahl method, with the amount of crude protein in the mushroom determined based on nitrogen content using a conversion factor (N) of 4.38 (Silva et al., 2007; Tsai et al., 2008). Glucose was measured using the method developed by Somogyi (1945) and Nelson (1944), and total sugar was calculated using the antrona method.

For the measurement of minerals, analyses were performed in triplicate with $0.5 \mathrm{~g}$ of dry mushroom for each strain or species. Calcium, magnesium, copper, zinc and iron were measured in Atomic Absorption Spectrometer AA-50 model GTA-110 (Agilent Technologies, Santa Clara, CA, United States). Phosphorus and sulfur were measured by spectrophotometry at $420 \mathrm{~nm}$ and boron at $540 \mathrm{~nm}$ in Spectrophotometer LAMBDA 25 (PerkinElmer, Waltham, MA, United States) while potassium was measured using a Flame Spectrophotometer model B-262 (Micronal, São Paulo, SP, Brazil) (Malavolta et al., 1997).

\section{Statistical analysis}

The means of the results were evaluated using analysis of variance (ANOVA), and the Scott-Knott test was used to compare differences $(p<0.05)$ among the $\beta$-glucan content, methods of quantitation of $\beta$-glucan and chemical composition. The SISVAR software (Ferreira, 2011) was used for the statistical analysis.

\section{RESULTS AND DISCUSSION}

\section{$\beta$-Glucan content}

$\beta$-Glucan extraction from the fungal cell wall can be done using several methods. The method described by Prosky et al. (1988) has been used, with some variations, to extract this polysaccharide for later quantification from soluble and insoluble fiber contained in the fungal cell wall (Dallies et al., 1998; Manzi and Pizzoferrato, 2001; Park et al., 2003; Brauer et al., 2008; Manzi et al., 2004).

In this work, a modified version of the method described by Prosky et al. (1988) was used to extract $\beta$ glucan, which was later quantified by spectrophotometry and HPLC. In addition to the $A$. subrufescens strains, other mushroom species were analyzed for comparison. The results of the $\beta$-glucan measurements are shown in Table 2. No significant differences were found when results obtained using the different quantification methods (spectrophotometry and HPLC) were compared. The samples quantified by the two tested methods were prepared using the same methods of extract preparation and filtration through filter paper as well as a $0.20 \mu \mathrm{m}$ ultrafilter membrane. Filtration through an ultrafilter membrane is of extreme importance for avoiding overestimation of the amount of $\beta$-glucan and is also necessary prior to HPLC analysis to avoid column block- 
Table 2. $\beta$-Glucan concentration $\left(\mathrm{g} \mathrm{Kg}^{-1}\right)$ of edible and medicinal mushroom samples determined by enzimatic method and by HPLC.

\begin{tabular}{lcc}
\hline Sample $^{*}$ & HPLC & Enzimatic method \\
\hline LE & $81.2 \pm 1.29 \mathrm{~A}$ & $90.0 \pm 1.43 \mathrm{~A}$ \\
PO & $89.2 \pm 0.68 \mathrm{~A}$ & $96.3 \pm 2.04 \mathrm{~A}$ \\
PE & $60.0 \pm 0.29 \mathrm{~B}$ & $67.2 \pm 1.95 \mathrm{~B}$ \\
CS10 & $57.5 \pm 0.81 \mathrm{~B}$ & $60.3 \pm 0.43 \mathrm{~B}$ \\
PC & $48.7 \pm 0.85 \mathrm{C}$ & $70.3 \pm 0.83 \mathrm{~B}$ \\
CS7 & $42.0 \pm 0.65 \mathrm{C}$ & $50.0 \pm 1.00 \mathrm{C}$ \\
CS9 & $40.0 \pm 0.29 \mathrm{C}$ & $42.7 \pm 0.71 \mathrm{C}$ \\
CS5 & $38.4 \pm 0.38 \mathrm{C}$ & $41.0 \pm 1.10 \mathrm{C}$ \\
CS2 & $30.5 \pm 0.50 \mathrm{D}$ & $32.6 \pm 1.22 \mathrm{C}$ \\
AB & $29.9 \pm 0.84 \mathrm{D}$ & $33.6 \pm 1.02 \mathrm{C}$ \\
CS1 & $27.0 \pm 1.25 \mathrm{D}$ & $21.1 \pm 0.67 \mathrm{C}$ \\
\hline
\end{tabular}

Values followed by same letters in the column do not differ among themselves, by Scott-Knott test $(p<0.05) .{ }^{*}$ CS1 a CS10: $A$. subrufescens strains; $\mathrm{AB}, A$. bisporus; LE: $L$. edodes; PE, P. eryngii; PC, P. sajor-caju; PO, P. ostreatus.

age. For spectrophotometric analysis, ultrafiltration or ultracentrifugation of the sample is important because at the end of the extraction process, small particles present in the sample may affect the absorbance reading, resulting in an overestimation of the $\beta$-glucan content. Park et al. (2003) extracted $\beta$-glucan from $A$. subrufescens mushrooms using the method of Prosky et al. (1988); however, these authors did not report a second filtration of the samples (through an ultrafilter membrane) before submitting them to spectrophotometric analysis.

The authors (Park et al., 2003) found that the concentration of $\beta$-glucan varied from 76.0 to $101.0 \mathrm{~g} \mathrm{Kg}^{-1}$ of dehydrated mushroom. These values are higher than the ones obtained in the present study, in which the highest $\beta$-glucan concentrations were 50.0 and $60.3 \mathrm{~g} \mathrm{Kg}$ ${ }^{1}$ for strains CS7 and CS10, respectively. Different strains may have different amounts of $\beta$-glucan, but because ultrafiltration was not used by Park et al. (2003), it is possible that their results were an overestimation.

Among $A$. subrufescens strains, the highest $\beta$-glucan content was seen in the CS10 strain $\left(60.3 \mathrm{~g} \mathrm{Kg}^{-1}\right)$, followed by the CS7 strain $\left(50.0 \mathrm{~g} \mathrm{Kg}^{-1}\right)$; the lowest $\beta$ glucan content was seen in the CS1 strain $\left(21.1 \mathrm{~g} \mathrm{Kg}^{-1}\right)$. Therefore, the CS7 and CS10 strains of $A$. subrufescens, which contained higher concentrations of $\beta$-glucan than the others, may have a greater potential for commercial exploitation.

In the comparison between species, the highest $\beta$ glucan contents were seen in $L$. edodes $\left(90.0 \mathrm{~g} \mathrm{Kg}^{-1}\right)$ and $P$. ostreatus $\left(96.3 \mathrm{~g} \mathrm{Kg}^{-1}\right)$, followed by $P$. sajor-caju $(70.3$ $\left.\mathrm{g} \mathrm{Kg}^{-1}\right)$ and $P$. eryngii $\left(67.2 \mathrm{~g} \mathrm{Kg}^{-1}\right)$. Several studies have highlighted the medicinal potential of $A$. subrufescens mushrooms (Bellini et al., 2006; Machado et al., 2005; Menoli et al., 2001; Oliveira et al., 2002), which is usually correlated with $\beta$-glucan content (Firenzuoli et al., 2008). However, in this work, $P$. ostreatus and $L$. edodes mushrooms were the species that contained the highest amounts of this polysaccharide. It is known that the medicinal properties of mushrooms are related to the type of linkages in their polysaccharide branches as well as the total quantity of polysaccharides (Siqueira et al., 2011; Kawagishi et al., 1989).

A comparison of the two $\beta$-glucan quantification methods (spectrophotometry and HPLC) used in this study shows that the spectrophotometric method may be the better choice for this type of analysis because it is a quicker and easier method to execute. It is important to observe that, except for $P$. sajor-caju, all other species and strains kept the same relative positions with regard to $\beta$-glucan content when measured by either method. In other words, the species with higher $\beta$-glucan concentrations when measured by HPLC also had higher concentrations under the spectrophotometric analysis (Table 2).

Shimizu et al. (2003) reported using the same extraction method described in this work for the $\beta$-glucan analysis of two strains of Pholiota adiposa mushrooms and observed meaningful differences between the strains. These results corroborate the idea that different strains of the same species may contain different amounts of $\beta$-glucan, as was observed in the present study.

Rhee et al. (2008) reported $\beta$-glucan extraction from Inonotus obliquus mushrooms using two methods. The first method was by enzymatic extraction, using Termamyl and amyloglucosidase enzymes, a method similar to the one used in the present study. The second method consisted of alkaline extraction in sodium carbonate-bicarbonate buffer $(\mathrm{pH} 10)$, followed by treatment with $\mathrm{HCl}$. According to the authors, no significant differences were observed between the two extraction methods; this finding demonstrates that different methods may be used to extract $\beta$-glucan without compromising the validity of the results.

However, Manzi and Pizzoferrato (2000) reported $\beta$ glucan measurements in different Pleurotus and $L$. edodes species that were much lower than the values reported in other studies. According to those authors, $\beta$ glucan concentrations of $5.3 \mathrm{~g} \mathrm{Kg} \mathrm{k}^{-1}$ for Pleurotus pulmonarius, $3.8 \mathrm{~g} \mathrm{Kg}^{-1}$ for $P$. ostreatus and $2.2 \mathrm{~g} \mathrm{Kg}^{-1}$ for $L$. edodes were observed. However, in that study, the samples were subjected to lichenase hydrolysis and further degradation by $\beta$-glucosidase, instead of acid hydrolysis, prior to $\beta$-glucan analysis.

Enzymatic hydro-lysis ensures that glucose is released only from $\beta$-glucan; however, the hydrolysis may be incomplete. Acid hydroly-sis is normally complete, although it is nonspecific. Given these facts, acid hydrolysis may be a good method for $\beta$-glucan analysis in mushrooms, considering that the insoluble fraction of mushrooms contains mainly $\beta$-glucan, in addition to some 
Table 3. Chemical and nutritional composition $\left(\mathrm{g} \mathrm{Kg}^{-1}\right)$ of dry mushrooms from distinct Agaricus subrufescens strains.

\begin{tabular}{lcccccc}
\hline Strain & Protein & Lipid & Nifest & Fiber & Ash & Moisture \\
\hline CS1 & $245.0 \pm 2.01 \mathrm{~B}$ & $18.6 \pm 0.08 \mathrm{~A}$ & $383.7 \pm 1.6 \mathrm{C}$ & $165.0 \pm 0.17 \mathrm{C}$ & $63.6 \pm 0.25 \mathrm{C}$ & $124.1 \pm 0.28 \mathrm{~A}$ \\
CS5 & $270.7 \pm 0.50 \mathrm{C}$ & $17.0 \pm 0.10 \mathrm{~A}$ & $349.1 \pm 1.5 \mathrm{D}$ & $175.0 \pm 0.17 \mathrm{~B}$ & $71.7 \pm 0.11 \mathrm{~A}$ & $116.5 \pm 0.92 \mathrm{~B}$ \\
CS7 & $220.8 \pm 0.46 \mathrm{~A}$ & $17.0 \pm 0.10 \mathrm{~A}$ & $431.5 \pm 0.49 \mathrm{~A}$ & $170.0 \pm 0.15 \mathrm{C}$ & $63.7 \pm 0.19 \mathrm{C}$ & $97.0 \pm 0.43 \mathrm{C}$ \\
CS9 & $233.7 \pm 0.46 \mathrm{~A}$ & $18.4 \pm 0.09 \mathrm{~A}$ & $404.8 \pm 0.96 \mathrm{~B}$ & $183.0 \pm 0.66 \mathrm{~A}$ & $67.2 \pm 0.07 \mathrm{~B}$ & $92.9 \pm 0.09 \mathrm{C}$ \\
CS10 & $248.4 \pm 1.11 \mathrm{~B}$ & $17.9 \pm 0.09 \mathrm{~A}$ & $416.1 \pm 1.25 \mathrm{~B}$ & $163.0 \pm 0.19 \mathrm{C}$ & $67.5 \pm 0.06 \mathrm{~B}$ & $87.1 \pm 0.15 \mathrm{D}$ \\
\hline
\end{tabular}

Values followed by same letters, in columns, do not differ among themselves by Scott-Knott test $(p<0.05)$. Values overwritten represent average pattern deviation.

Table 4. Average values of phenolic compounds and sugars $\left(\mathrm{g} \mathrm{Kg}^{-1}\right)$ in $A$. subrufescens mushrooms in dehydrated matter.

\begin{tabular}{lccc}
\hline Strain & Reducing sugar & Non reducing sugar & Polyphenols \\
\hline CS1 & $0.54 \pm 0.01 \mathrm{~A}$ & $6.1 \pm 0.05 \mathrm{~B}$ & $18.2 \pm 0.42 \mathrm{~A}$ \\
CS5 & $0.45 \pm 0.01 \mathrm{C}$ & $4.5 \pm 0.01 \mathrm{C}$ & $22.0 \pm 0.11 \mathrm{~A}$ \\
CS7 & $0.48 \pm 0.02 \mathrm{~B}$ & $7.6 \pm 0.10 \mathrm{~A}$ & $19.6 \pm 0.26 \mathrm{~A}$ \\
CS9 & $0.44 \pm 0.02 \mathrm{C}$ & $6.3 \pm 0.02 \mathrm{~B}$ & $17.8 \pm 0.08 \mathrm{~A}$ \\
CS10 & $0.39 \pm 0.01 \mathrm{D}$ & $5.2 \pm 0.01 \mathrm{C}$ & $16.5 \pm 0.12 \mathrm{~A}$ \\
\hline
\end{tabular}

Values followed by same letters, in columns, do not differ among themselves by Scott-Knott test $(p<0.05)$. Values overwritten represent average pattern deviation.

chitin and hemicellulose. The sugars produced by the hydrolysis of chitin and hemicellulose are different from the glucose released from glucan hydrolysis; thus, acid hydrolysis, followed by spectrophotometric measurement of the free glucose released, allows for an efficient quantification of $\beta$-glucan. According to Park et al. (2003), the method described by Prosky et al. (1988) and modified by the Japanese Food Analysis Center is the official method in Japan for the analysis of $\beta$-glucan.

Rhee et al. (2008) attempted unsuccessfully to standardize a method of $\beta$-glucan measurement in $I$. obliquus mushrooms by testing two quantification methods (a gravimetric method and HPLC analysis). Their results were not statistically distinct (101.0 to 107.0 $\mathrm{g} \mathrm{Kg}^{-1}$ dehydrated matter by the gravimetric method and 81.0 to $83.0 \mathrm{~g} \mathrm{Kg}^{-1}$ dehydrated matter by HPLC). The authors suggested that HPLC measurement would be more appropriate for quantifying $\beta$-glucan when it is present at high levels.

The method of extracting $\beta$-glucan used in this work has proven to be efficient for $A$. subrufescens mushrooms and for other mushroom species. Both of the quantification methods (HPLC and spectrophotometry) were found to be equally efficient for measuring the amount of $\beta$-glucan in the mushroom samples. The amount of $\beta$-glucan in the mushroom samples was the same for both methods. Methods of $\beta$-glucan by HPLC are more laborious and more expensive than spectrophotometric methods.

\section{Chemical analysis}

With the aim of better understanding the nutritional properties of $A$. subrufescens, nutritional characteristics, concentration of phenolic compounds and mineral composition of five strains were evaluated. Significant differences $(p<0.05)$ were observed for all of the nutritional variables assessed, except for fat content (Table 3). Among the five strains, the CS5 strain had the highest concentrations of protein $\left(270.7 \mathrm{~g} \mathrm{Kg}^{-1}\right)$ and ash $\left(71.7 \mathrm{~g} \mathrm{Kg}^{-1}\right)$. However, the CS9 strain had the highest crude fiber concentration $\left(183.0 \mathrm{~g} \mathrm{Kg}^{-1}\right)$, followed by the CS5 strain $\left(175.0 \mathrm{~g} \mathrm{Kg}^{-1}\right)$. These data are very similar to those reported by Tsai et al. (2008) for samples of an $A$. subrufescens strain purchased in a market in Taiwan. Crude fiber is composed of multiple polysaccharides, including $\beta$-glucan, which is a major target for studies of compounds with antitumor activity (Bellini et al., 2006; Firenzuoli et al., 2008; Machado et al., 2005; Park et al., 2003). Therefore, fiber content may be related to the concentration of $\beta$-glucan in mushrooms. There were no significant differences with regard to the percentage of fat, and all of the strains contained less than $20 \mathrm{~g} \mathrm{Kg}^{-1}$ fat. A low concentration of lipids is generally considered a common feature of mushrooms (Liu et al., 2005). The various $A$. subrufescens strains showed statistically significant differences in the concentrations of reducing and non-reducing sugars (Table 4). The CS7 strain had the highest concentration of non-reducing sugars $(7.6 \mathrm{~g}$ 
Table 5. Average mineral composition $\left(\mathrm{g} \mathrm{Kg}^{-1}\right)$ of mushrooms from different $A$. subrufescens strains in dried matter.

\begin{tabular}{|c|c|c|c|c|c|c|c|c|c|c|}
\hline Strain & $\mathbf{P}$ & $\mathbf{K}$ & $\mathrm{Ca}$ & $\mathrm{Mg}$ & $\mathbf{S}$ & B & $\mathrm{Cu}$ & Mn & $\mathrm{Zn}$ & $\mathrm{Fe}$ \\
\hline CS1 & $11.2 \pm 0.03 \mathrm{C}$ & $19.4 \pm 0.05 \mathrm{~A}$ & $3.8 \pm 0.02 \mathrm{~A}$ & $1.3 \pm 0.01 \mathrm{~A}$ & $3.7 \pm 0.01 B$ & $32.0 \pm 2.11 \mathrm{~A}$ & $0.0286 \pm 0.38 \mathrm{C}$ & $0.0085 \pm 0.55 B$ & $0.0620 \pm 4.70 \mathrm{~B}$ & $0.0703 \pm 7.77 \mathrm{~B}$ \\
\hline CS5 & $12.3 \pm 0.07 \mathrm{~A}$ & $19.5 \pm 0.02 A$ & $3.4 \pm 0.02 \mathrm{~A}$ & $1.3 \pm 0.01 \mathrm{~A}$ & $4.1 \pm 0.01 \mathrm{~A}$ & $40.0 \pm 1.50 \mathrm{~A}$ & $0.0539 \pm 0.65 A$ & $0.0082 \pm 0.29 \mathrm{~B}$ & $0.0515 \pm 0.57 \mathrm{D}$ & $0.0912 \pm 6.53 \mathrm{~A}$ \\
\hline CS7 & $10.8 \pm 0.01 \mathrm{D}$ & $19.4 \pm 0.03 \mathrm{~A}$ & $1.8 \pm 0.01 \mathrm{~B}$ & $1.3 \pm 0.01 \mathrm{~A}$ & $3.5 \pm 0.01 \mathrm{C}$ & $34.0 \pm 1.76 \mathrm{~A}$ & $0.0306 \pm 0.15 B$ & $0.0072 \pm 0.10 \mathrm{C}$ & $0.0463 \pm 0.87 E$ & $0.0678 \pm 0.49 B$ \\
\hline CS9 & $10.8 \pm 0.02 \mathrm{D}$ & $19.5 \pm 0.02 \mathrm{~A}$ & $3.6 \pm 0.03 \mathrm{~A}$ & $1.4 \pm 0.01 \mathrm{~A}$ & $3.4 \pm 0.01 \mathrm{C}$ & $21.7 \pm 0.06 \mathrm{~A}$ & $0.0237 \pm 0.25 \mathrm{D}$ & $0.0094 \pm 0.40 \mathrm{~A}$ & $0.0560 \pm 0.68 \mathrm{C}$ & $0.0670 \pm 0.83 B$ \\
\hline CS10 & $11.6 \pm 0.02 B$ & $19.4 \pm 0.01 \mathrm{~A}$ & $3.7 \pm 0.01 \mathrm{~A}$ & $1.5 \pm 0.01 \mathrm{~A}$ & $3.7 \pm 0.01 B$ & $20.0 \pm 0.60 \mathrm{~A}$ & $0.0274 \pm 0.93 \mathrm{C}$ & $0.0080 \pm 0.12 \mathrm{~B}$ & $0.0679 \pm 0.84 \mathrm{~A}$ & $0.0690 \pm 0.60 \mathrm{~B}$ \\
\hline
\end{tabular}

Values followed by same letters, in columns, do not differ among themselves by Scott-Knott test $(p<0.05)$. Values overwritten represent average pattern deviation.

$\mathrm{Kg}^{-1}$ ) among the five strains; however, the values obtained were very low overall, and the concentration of reducing sugars was negligible. $A$ subrufescens mushrooms are known to possess antioxidant properties, and this characteristic in mushrooms is associated with the presence of phenolic compounds (Barros et al., 2008; Elmastas et al., 2007). The measurement of phenolic compounds from different strains of $A$ subrufescens mushrooms reported in the present study did not show any significant differences between strains (Table 4). The values are similar to those found for Agaricus arvensis $\left(28.3 \mathrm{~g} \mathrm{Kg}^{-1}\right)$ and are lower than those reported for species from other genera, such as $L$. edodes $(47.9 \mathrm{~g} \mathrm{Kg}$ $\left.{ }^{1}\right)$, Volvariella volvacea $\left(150.0 \mathrm{~g} \mathrm{Kg}^{-1}\right)$, Leucopaxillus giganteus $\left(62.9 \mathrm{~g} \mathrm{Kg}^{-1}\right)$ and Sarcodon imbricatus (37.6 g Kg${ }^{-1}$ ) (Barros et al., 2007; Cheung et al., 2003)

The mineral composition of $A$. subrufescens mushrooms is represented in Table 5 , with significant differences $(p<0.05)$ between strains treatments. No significant differences were found between strains for potassium, magnesium, boron and iron. The CS5 strain contained the highest concentrations of phosphorus, sulfur and copper of all of the strains. The highest concentration of manganese was found in the CS9 strain, and the highest concentration of zinc in the CS1 strain. The CS7 strain contained significantly the lowest concentrations of calcium and manganese. Besides
Besides, CS7 was among the strains with lowest phosphorus, sulfur and iron concentrations.

It is worth noting that the results presented here refer to dry, rather than fresh, mushrooms. Considering that the amount of moisture in the fresh mushrooms varied from 832.5 to $917.5 \mathrm{~g} \mathrm{Kg}$ 1 depending on the strain, the dry components account for only 82.5 to $167.5 \mathrm{~g} \mathrm{Kg}^{-1}$ of the total composition of the mushrooms. However, fresh mushrooms should be considered an important source of minerals and fiber and a better source of protein than other vegetables. Furthermore, it is important to emphasize that the results presented in this work demonstrate that the genetic differences observed by Tomizawa et al. (2007) result in different chemical and nutritional properties for different strains. Experiments with different strains of Pleurotus spp., Flammulina velutipes, Lentinula edodes and Agaricus bisporus also demonstrated differences in chemical composition among strains of the same species (Toro et al., 2006; Calonje et al., 1995; Yang et al., 2001).

\section{Conclusions}

Fresh $A$. subrufescens mushrooms are not considered to be a high-protein food. However, they are a good source of fiber and minerals, in addition to being low in fat. Therefore, these mushrooms can be considered a beneficial source of nutrients in the diet. Two different methods of quantification (HPLC and spectrophotometry) may be used to efficiently measure the amount of $\beta$ glucan in $A$. subrufescens. Spectrophotometry presents the advantages of being quicker and lower in cost, allowing for routine use in the laboratory. Based on these characteristics, this technique may be suggested as the standard for measurement of the $\beta$-glucan concentration in edible and medicinal mushrooms.

\section{ACKOWLEDGEMENTS}

Coordenação de Aperfeiçoamento de Pessoal de Nível Superior (CAPES), Fundação de Amparo a Pesquisa do Estado de Minas Gerais (FAPEMIG) and Conselho Nacional de Desenvolvimento Científico e Tecnológico (CNPq) are thank for the financial support.

\section{REFERENCES}

Adams LS, Phung S, Wu X, Ki L, Chen S (2008). White button mushroom (Agaricus bisporus) exhibits antiproliferative and proapoptotic properties and inhibits prostate tumor growth in athymic mice. Nutr. Cancer. 60:744-756.

Association of Official Agricultural Chemists (AOAC) (1992). Official methods of analysis of the Association of the Agricultural Chemists. 12 ed. Washington:A.O.A.C. USA.

Association of Official Analytical Chemists (AOAC) (2000). Official methods of the Association of Official Analytical Chemists. 17 ed. Gaithersburg: A.O.A.C. USA. 
Barros L, Falcão S, Baptista P, Freire C, Vilas-Boas M, Ferreira ICFR (2008). Antioxidante activity of Agaricus sp. Mushrooms by chemical, biochemical and electrochemical assays. Food Chem. 111:61-66.

Barros L, Ferreira M, Queirós B, Ferreira ICFR, Baptista P (2007). Total phenols, ascorbic acid, $\beta$-carotene and lycopene in Portuguese wild edible mushrooms and their antioxidant activities. Food Chem. 103:413-419.

Bellini MF, Angeli JPF, Matuo R, Terezan AP, Ribeio LR, Mantovani MS (2006). Antigenotoxicity of Agaricus blazei mushroom organic and aqueous extracts in chromosomal aberration and cytokinesis block micronucleus assays in $\mathrm{CHO}-\mathrm{K} 1$ and HTC cells. Toxicol. in vitro. 20:355-360.

Bonatti M, Karnopp P, Soares HM, Furlan SA (2004). Evaluation of Pleurotus ostreatus and Pleurotus sajor-caju nutritional characteristics when cultivated in different lignocellulosic wastes. Food Chem. 88:425-428.

Brauer D, Kimmons T, Phillips M (2008). Comparison of Two Methods for the Quantitation of $\beta$-Glucans from Shiitake Mushrooms. J. Herbs, Spices Med. Plants. 13:15-26.

Calonje M, Mendonza CG, Cabo AP, Novaes-Ledieu M (1995). Some significant differences in wall chemistry among four commercial Agaricus bisporus strains. Curr. Microbiol. 30:111-115.

Carbonero ER, Gracher AHP, Smiderle FR, Rosado FR, Sassaki GL, Gorin PAJ, lacomini M (2006). A $\beta$-glucan from the fruit bodies of edible mushrooms Pleurotus eryngii and Pleurotus ostreatoroseus. Carbohydr. Polym. 66:252-257.

Chang ST, Miles PG (2004). Mushrooms:cultivation, nutritional value, medicinal effect, and environmental impact. CRC Press, Boca Raton, Florida, USA.

Cheung LM, Cheung PCK, Ooi VEC (2003). Antioxidant activity and total phenolics of edible mushroom extracts. Food Chem. 81:249255.

Colauto NB, Dias ES, Gimenes MA, Eira AF (2002). Genetic characterization of isolates of the basidiomycete Agaricus blazei by RAPD. Braz. J. Microbiol. 33:131-133.

Dallies N, François J, Paquet V (1998). A new method for quantifative determination of polysaccharides in the yeast cell wall. Application on the cell wall defective mutants of Saccharomyces cerevisiae. Yeast. 14:1297-1306.

Dias ES, Koshimo EMS, Schwan RF, Silva R (2003). Cultivo do cogumelo Pleurotus sajor-caju em diferentes resíduos agrícolas. Cienc. Agrotecnol. 27:1363-1369.

Dong Q, Yao J, Yang X, Fang J (2002). Structural characterization of water-soluble of $\beta$-D-glucan from fruiting bodies of Agaricus blazei Murr. Carbohydr. Res. 337:1417-1421.

Elmastas M, Isildak O, Turkekul I, Temur N (2007). Determination of antioxidant activity and antioxidant compounds in wild edible mushrooms. J. Food Compos. Anal. 20:337-345.

Fan L, Soccol AT, Pandey A, Soccol CR (2007). Effect of nutritional and environmental conditions on the production of exo-polysaccharide of Agaricus brasiliensis by submerged fermentation and its antitumor activity. Food Sci. Technol. 40:30-35.

Ferreira DF (2011). Sisvar: a computer statistical analysis system. Cienc. Agrotecnol. 35:1039-1042.

Firenzuoli F, Gori L, Lombardo G (2008). The medicinal mushroom Agaricus blazei Murrill:Review of literature and pharmacotoxicological problems. J. Evidence-Based Complementary Altern. Med. 5:3-15.

Guardia LM, Venturella G, Venturella F (2005). On the chemical and nutritional value of Pleurotus taxa growing on umbelliferous plants (Apiaceae). J. Agric. Food Chem. 53:5997-6002.

Huang S, Mau J (2006). Antioxidant properties of methanolic extracts from Agaricus blazei with various doses of $y$-irradiation. Food Sci. Technol. 39:707-716.

Kawagishi $\mathrm{H}$, Inagaki $\mathrm{R}$, Kanao $\mathrm{T}$, Mizuno $\mathrm{T}$, Shimura $\mathrm{K}$, Ito $\mathrm{H}$, Carbohydr. Res. 186:267-273.

Liu J, Vijayakumar C, Hall III CA, Hadley M, Wolf-Hall CE (2005). Sensory and chemical analyses of oyster mushrooms (Pleurotus sajor- sajor-caju) harvested from different substrates. J. Food Sci. 70:586-592.

Machado MP, Filho ER, Terezan AP, Ribeiro LR, Mantovani MS (2005). Cytotoxicity, genotoxicity and antimutagenicity of hexane extracts of
Agaricus blazei determined in vitro by the comet assay and $\mathrm{CHO} /$ HGPRT gene mutation assay. Toxicol. In Vitro. 19:533-539.

Malavolta E, Vitti GC, Oliveira SA (1997). Avaliação do estado nutricional das plantas. Princípios e Aplicações. Potafos, Piracicaba, São Paulo, Brasil.

Manzi P, Marconi S, Aguzzi A, Pizzoferrato L (2004). Commercial mushrooms: nutritional quality and effect of cooking. Food Chem. 84:201-206.

Manzi P, Pizzoferrato L (2000). Beta-glucans in edible mushrooms. Food Chem. 68:315-318.

Manzi P, Pizzoferrato $L$ (2001). Nutritional value of mushrooms widely consumed in Italy. Food Chem. 73:321-325.

McClear BV, Glennie-Holmes M (1985). Enzymic quantification of (1-3) (14) - $\beta$-D-glucan in barley and malt. J. Inst. Brew. 91:285-295.

Menoli RCN, Mantovani MS, Ribeiro LR, Gunter S, Jordão BQ (2001). Antimutagenic effects of the mushroom Agaricus blazei Murill extracts on V79 cells. Mutat. Res. 496:5-13.

Nelson NA (1944). A photometric adaptation of Somogyi method for the determination of glucose. J. Biol. Chem. 153:375-380.

Oliveira JM, Jordão BQ, Ribeiro LR, Eira AF, Mantovani MS (2002). Anti-genotoxic effect of aqueous extracts of sun mushroom (Agaricus blazei Murill lineage 99/26) in mammalian cells in vitro. Food Chem. Toxicol. 40:15-20.

Park YK, Ikegaki M, Alencar SM, Aguiar AL (2003). Determinação da concentração de $\beta$-glucano em cogumelo Agaricus blazei Murill por método enzimático. Cienc. Tecnol. Aliment. 23:312-316.

Pramanik M, Chakraborty I, Mondal S, Islam SS (2007). Structural analysis of a water-soluble glucan (Fr. I) of an edible mushroom, Pleurotus sajor-caju. Carbohydr. Res. 342:2670-2675.

Prosky L, Asp N, Schweizer TF, DeVries JW, Furda I (1988). Determination of insoluble, soluble, and total dietary fiber in foods and food products: interlaboratory study. J. - Assoc. Off. Anal. Chem. 71:1017-1023.

Ragunathan R, Swaminathan K (2003). Nutritional status of Pleurotus spp. grown on various agro-wastes. Food Chem. 80:371-375.

Rhee SJ, Cho SY, Kim KM, Cha D, Park H (2008). A comparative study of analytical methods for alkali-soluble $\beta$-glucan in medical mushroom, Chaga (Inonotus obliquus). Food Sci. Technol. 41:545549.

Schwan RF, Mendonça AT, Silva Júnior JJ, Rodrigues V, Wheals AE (2001). Microbiology and Physiology of cachaça (aguardente) fermentations. Antonie van Leeuwenhoek. 79:89-96.

Shimadzu. Application data book (1998). Japan: Shimadzu, (Catálogo C190-E001).

Shimizu K, Fujita R, Kondo R, Sakai K, Kaneko S (2003). Morphological features and dietary functional components in fruit bodies of two strains of Pholiota adiposa grown on artificial beds. J. Wood Sci. 49:193-196.

Silva EG, Dias ES, Siqueira FG, Schwan RF (2007). Chemical analysis of fructification bodies of Pleurotus sajor-caju cultivated in several nitrogen concentrations. Cienc. Tecnol. Aliment. 27:72-75.

Siqueira FG, Dias ES, Silva R, Martos ET, Rinker DL (2009). Cultivation of Agaricus blazei ss. heinemann using different soils as source of casing materials. Sci. Agric. 66:827-830.

Siqueira FG, Martos ET, Silva EG, Silva R, Dias ES (2011). Biological efficiency of Agaricus brasiliensis cultivated in compost with nitrogen concentrations. Hortic. Bras. 29:157-161.

Somogy M (1945). A New Reagent for Determination of Sugars. A new Sugar Reagent. J. Biol. Chem. 160:61-68.

Tomizawa MM, Dias ES, Assis LJ, Gomide PHO, Santos JB (2007). Genetic variability of mushroom isolates Agaricus blazei using markers RAPD. Cienc. Agrotecnol. 31:1242-1249.

Toro GV, Vaga RC, Garín-Aguiar ME, Lara HL (2006). Biological quality of proteins from three strains of Pleurotus spp. Food Chem. 94:494497.

Tsai S, Tsai H, Mau J (2008). Non-volatile taste components of Agaricus blazei, Agrocybe cylindracea and Boletus edulis. Food Chem. 107:977-983.

Yang J, Lin H, Mau J (2001). Non-Volatile taste components of several commercial mushrooms. Food Chem. 72:465-471. 